\title{
A COMPARATIVE USE OF COSMOPOLITAN AND MULTIPLE HEALTH SERVICES IN THE LAGOS METROPOLIS
}

\author{
Olugbemi Moloye
}

\section{Introduction}

It is an aphorism that in a changing society people are confronted with decisionmaking situations in which a choice between new and old structures has to be made. Cosmopolitan faith-healing and the traditional herbal medical systems represent one such apparent dilemma that faces the citizens of non-Western societies. A number of health analysts has identified several fallacies in the commonly-held assumption which lies behind the traditional-modern dichotomy. In contrast to the idea that old traditions are uniformly displaced by new changes, Gusfield (1967) contends that the acceptance of a form does not necessarily lead to the disappearance of an old one. Both "magic" and modern medicine can exist side by side, and used alternatively by the same people.

The city of Lagos is reputed for her heavy concentration of cosmopolitan healthcare and infrastructural facilities. In fact, the history of cosmopolitan medicine in the country can hardly be divorced from the history of European contact with Nigeria, Lagos being the entrepot. It was reported by Schram (1971) that within the first two years of colonial occupation, a well-staffed, well-stocked and an expensive hospital was established to provide the medical needs of European residents in Lagos. That single act

led ineluctably to the establishment of cordon sanitaire -in areas designated "Sanitary Districts" and designed to prevent the contraction of epidemic diseases which the Europeans thought was endemic among Africans (Lugard 1923). 
Ever since Nigeria attained political independence in 1960, hundreds of millions of naira have been invested in major attempts to provide health care of the cosmopolitan type to all Nigerians. This is more so in metropolitan Lagos where it is politically expedient to install infrastructural cosmopolitan health facilities, irrespective of their functional utility. Nonetheless, the recipient populations have remained ambivalent, to a large degree, to the gnosology and etiology of the cosmopolitan medical system at the same time as it utilizes its curative resources eclectically.

The failure of total acceptance of the cosmopolitan medical system in Africa, Asia and Latin America has been the focus of social scientists in the last four decades (Foster 1972; Ganedo 1974).

While there is a paucity of literature that explains the multiple use of health facilities, there is, however, sufficient literature on reasons for the rejection of cosmopolitan health facilities in non-Western societies. Foster (1951), for example, had argued that the mere availability of cosmopolitan medical resources would lead to their widespread utilization. Others have argued the demonstrability effect of the cosmopolitan health facility as being capable of convincing non-Western people of its superiority over trado-medical resources. In fact, Simmions (1955: 57-71) cited the overwhelming response of traditionally-oriented "populations to injection which has created the belief that medication without injection is incomplete". In justification of the infrequent use of cosmopolitan medical facilities, Foster and others have pointed to the pragmatic nature of peoples in Africa and Asia and explained that their reluctance stemmed not from, any inability to recognise the benefits of cosmopolitan medicine itself but from the vast social gap which stood between the peasant recipients and the urban/elite providers, whose frequent disdain for their peasant, "low class" and superstitious clients led to the disrespectful, and occasionally humiliating, treatment.

In addition, these analysts argue that such populations were accustomed to the personalised and intensive attention usually given by practitioners of herbal medicine but which the physicians' impersonal and made-to-order work schedule could not provide (Kane and Kane 1972; Behrhost 1973). The problem of economic cost has also been suggested by a number of analysts. It has been argued that the inability of peasant populations to utilise cosmopolitan medical facilities was due to its expensive economic costs. On the other hand, Lieben (1967) and Nolen (1974) have both argued that the use of cosmopolitan health facilities did not increase exponentially in societies where such facilities were free. 


\section{Annals of the Social Council of Nigeria}

\section{Objective}

The problem with these hypotheses is that they fail to address multiple use of health facilities as a phenomenon which adheres to particular patterns and do not view utilization patterns in relation to a complex of socio-cultural and institutional factors. More specifically, it needs to be pointed out that when a new medical system is introduced to a social group which has an indigenous medical system, the general use of the new medical system by the group is affected by cultural factors which are meaningfully related to the old and new medical systems and to the consequent latent functions of both. Thus, it may be hypothesised that:

The extent of use of cosmopolitan health facilities is directly related to situational and institutional factors as expressed in the social groups' shared worldview.

This implies that when alternative healing systems are available, a proportion of the population will make use of more than one. This multiple use suggests a measure of ambivalence which may appear to non-indigenes as a confused state of priorities and the social group worldview.

\section{Methodology}

Four representative areas (Surelere, Ikeja, Obalande and Shomolu) in metropolitan Lagos were selected for the study. These areas were stratified into two broad groups of middle-upper and lover classes. This was done by deliberate selections of two specific communities in the selected area to ensure comprehensive representativeness since the study cannot cover the whole selected area. Within each class areas, clusters of building blocks were identified and it was ensured that interviews were conducted among adults in every of the fifth household. Interviews were conducted by trained interviewers (university undergraduates) for a period of four weeks. In all, 850 adults were interviewed.

Each questionnaire contained both open-ended-and closed questions. For example, respondents were asked to identify specifically the types of diseases for which they normally use all available medical systems simultaneously. Information on socialdemographic characteristics, social and health status as well as attitude toward the use of health-care systems were sought, as this information impinges heavily on health behaviour. The data were organised to facilitate the measurement of different socioeconomic groups along the:

(a) pattern of use of facilities of medical systems;

(b) attitude toward multiple use of these medical system; and

(c) problem of access to health facilities. 


\section{Findings}

\section{SOCIO-DEMOGRAPHIC CHARACTERISTICS}

Table 1 is the socio-demographic profile of respondents. The Table reveals that $48 \%$ of respondents are in the professional cadre, constituting the largest proportion. This is not surprising in view of the fact that Lagos State has the largest concentration of educated and skilled Nigerians (Okosi 1988). In addition, the significance of Lagos as the political capital of Nigeria since colonial times as well as the commercial nerve-centre of the country is demonstrated by the fact that almost $29 \%$ of respondents are traders.

Table 1

SOCIO-DEMOGRAPHIC CHARACTERISTICS

No. $=\mathbf{8 5 0}$

\begin{tabular}{|c|c|c|}
\hline Sex & No, & $\%$ \\
\hline Male & 630 & 74.0 \\
\hline Female & 220 & 26.0 \\
\hline Age(year) & & \\
\hline $0-35$ & 150 & 17.7 \\
\hline $36-55$ & 500 & 58.8 \\
\hline Over 55 & 200 & 23.5 \\
\hline $\begin{array}{l}\text { Education } \\
\text { Illiterate }\end{array}$ & - & \\
\hline Post-secondary & 334 & 39.2 \\
\hline Post-university & 136 & 16.0 \\
\hline Technical & 380 & 44.7 \\
\hline Occupation & & \\
\hline Unemployed/Student & - & - \\
\hline Farming & - & - \\
\hline Traders/Self-employed & 247 & 29.0 \\
\hline Civil Servants & 195 & 23.0 \\
\hline Professional & 408 & 48.0 \\
\hline Income & & \\
\hline No Income & - & \\
\hline $4,000-8,000$ & 268 & 31.5 \\
\hline $8,001-12,000$ & 263 & 30.9 \\
\hline $12,001-16,000$ & 216 & 25.4 \\
\hline Over 16,000 & 83 & 9.8 \\
\hline No Response & 20 & 2.4 \\
\hline
\end{tabular}




\section{Annals of the Social Council of Nigeria}

\section{KNOWLEDGE AND UTILISATION OF HEALTH FACILITIES}

As mentioned earlier, Lagos has a unique place in the history of health development in Nigeria. This is indicated by the fact that more than 29\% (i.e. $78 \%$ ) checking of respondents are aware of the availability of a variety of health institutions which are located in close proximity to their places of residence.

The knowledge about the availability of health-care facilities is not necessarily tantamount to utilisation as this is largely dependent on a number of factors (Moloye 1988). For example, respondents were asked where they go for help if afflicted? Without hesitation, $92 \%$ of the respondents informed that they readily seek services from available health facilities but in accordance to their perceived efficacy. The respondents' ambivalence results from the multiplicity of medical systems available in the society which makes the use of any of them dependent on the perceived etiology and gnosology of the diseases. This is because a disease once classified in the indigenous taxonomy must be treated accordingly.

More importantly, Lagos metropolis is a migrant community where the indigenous population is less than $40 \%$ of the population. In view of the population composition within the metropolis, where the migrant population is still much attached to the way of life obtainable in their various roots and practise it accordingly, dependence on cultural practices becomes expedient as they have always provided solutions to personal problems. Many cross- cultural studies in health behaviour have identified continual patronage of any medical system on the amount of trust patrons have in the efficacy of the system. Consequently, trust plays a major role in the utilisation of such a medical system (Ademuwagun 1969).

\section{SOCIAL CLASS AND HEALTH USE}

It is indicated in Tables 2,3 and 4 that the simultaneous use of these medical systems is not confined to any socio-economic groups as respondents use them for different purposes. Table 2 is a summary of respondents' income brackets. The Table indicates that $20 \%$, (i.e. 170 of respondents), use facilities of cosmopolitan medicine singly, while $80 \%$, (i.e. 680), use all the three health-care systems severally. It is revealed in the Table that respondents who earn less than 148,000 annually constitute the largest number of multiple users (i.e. about 38\%) of the three medical systems, while the single largest user of cosmopolitan medicine alone are those respondents (41\%) who earn between 148,001 $-1412,000$ annually.

Apparently money is not the militating factor for multiple usage as only $10 \%$ of those earning more than 1416,000 annually, dualistically utilise the services of the three medical systems, while only $15 \%$ in a similar income bracket 'confine their health needs to cosmopolitan medicine only. 
Table 3 is a breakdown of multiple use of health facilities along the line of educational status. Generally, education is regarded as a great catalyst for social change, but it does not appear to deter the use of multiple health systems in this study. It is revealed in Table 3 that more than $15 \%$, (i.e. 105), of respondents with post- University education indulge in the multiple use of the three systems, while the remaining $85 \%$, who have no postUniversity education do similarly.

Out of the 170 respondents who depend solely on cosmopolitan medical facilities, about $79 \%$ of them belong to the professional class (doctors, lawyers, engineers, etc). In a similar category, $12 \%$ are civil servants while the self-employed are only $9 \%$ of respondents. On the other hand, in the category of multiple users, $26 \%$ are professionals, $53 \%$ are self-employed traders and businessmen while only $21 \%$ of multiple users are civil servants. This is certainly not unexpected as users who are not on salary would want to be doubly sure that they remain in a perfect state of well-being; hence the multiple use of all available health facilities.

\section{USE OF SINGLE HEALTH FACILITY (COSMOPOLITAN) BY DISEASE TYPES}

Tables 5, 6 and 7 indicate the use of cosmopolitan medicine for disease types according to socio-economic characteristics. These disease types fall within biomedieine. It is revealed in Table 5, for example, that 50\% of respondents who earn more than $1 * 16,000$ annually use cosmopolitan health services for hypertensive conditions while 53\% in

Table 2

USE OF HEALTH FACILITIES BY INCOME

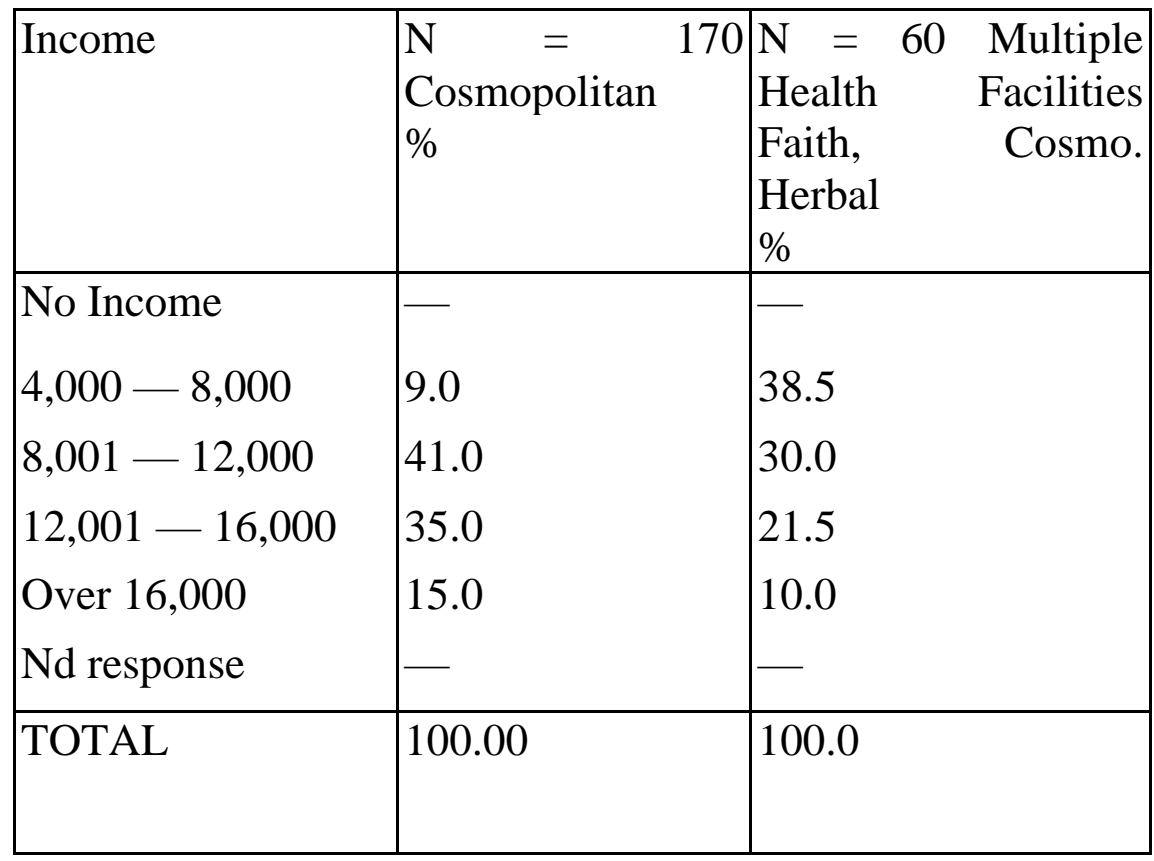


a similar income bracket use cosmopolitan health services solely to cure infectious and parasitic diseases. About 47\% (i.e. 80) of the respondents who earn less than N8,000 opt for obstetrical health facilities rather than traditional birth attendants in the delivery of babies, while respondents earning over N16,000 in the same category of health use are likely to have stopped having children since there was no response on the issue.

Table 6 indicates that a significant proportion of respondents with post-university education prefer the use of cosmopolitan health facilities solely for disease types identified much more than other groups of respondents. It is revealed in the Table that a significant proportion of university-educated respondents do not associate the therapeutic effects of traditional medicine with the disease listed in the Table. This is a clear indication that respondents who have better socio- economic characteristics prefer cosmopolitan health facilities solely for a category of disease types. This, no doubt, is because of their awareness and perception that such disease types fall within the therapeutic parameters of biomedicine. The assumption is confirmed further by Table 7 as the category of "professionals", who are better educated as mentioned earlier, rely more on cosmopolitan medicine in-greater proportion than any other category of occupation. For example, about $70 \%$ of the respondents use the services of cosmopolitan medicine for hypertensive problems while only $30 \%$ of the respondents who are civil servants, do similarly. The Table also shows that $60 \%$ of the respondents who are professionals rely on cosmopolitan medicine for stomach ulcers while only $15 \%$ of the respondents who are self-employed use similar therapeutic services. In sum, the essence of Table 7 is the perception of the therapeutic relevance of cosmopolitan medicine in the treatment of a category of ailments by respondents who have professional jobs and earn better income.

Table3

USE OF HEALTH FACILITIES BY EDUCATION

\begin{tabular}{|l|l|l|}
\hline \multirow{2}{*}{ Education } & $\mathrm{N}=170$ & $\mathrm{~N}=680$ Multiple \\
& $\begin{array}{l}\text { Cosmopolitan } \\
\%\end{array}$ & Health Facilities \\
\cline { 3 - 3 } & - & Faith 'Cosmo. Herbal \\
\hline No education & 58.0 & - \\
Post-secondary & 18.0 & 34.5 \\
Post-university & 24.0 & 50.4 \\
Technical & - & - \\
No response & 100 & 100 \\
\hline TOTAL & & \\
\hline
\end{tabular}


Table 4

USE OF HEALTH SERVICES BY OCCUPATION $\mathbf{N}=\mathbf{8 5 0}$

\begin{tabular}{|l|l|l|}
\hline Occupation & $\begin{array}{l}\mathrm{N}=170 \\
\text { Cosmopolitan \% }\end{array}$ & $\begin{array}{l}\text { Multiple } \\
\text { Facilities N = 680 }\end{array}$ \\
\cline { 3 - 3 } & & $\begin{array}{l}\text { Cosmo. } \\
\text { Herbal \% }\end{array}$ \\
\hline Unemployed & - & Faith \\
Professional & 79.0 & 26 \\
Civil servants & 12.3 & 21 \\
Self- & 9.0 & 53 \\
employed/Traders & & 100 \\
\hline TOTAL, & 100.0 & \\
\hline
\end{tabular}

Table 5

USE OF SINGLE FACILITIES FOR DISEASE TYPES BY INCOME No $=\mathbf{1 7 0}$

\begin{tabular}{|c|c|c|c|c|c|}
\hline $\begin{array}{l}\text { Selected Health } \\
\text { cases }\end{array}$ & $\begin{array}{l}\mathrm{N} 4,000 \\
-8,000\end{array}$ & 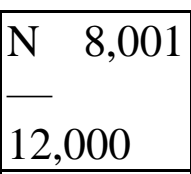 & $\begin{array}{l}\text { M } 1,200 \\
16,000 \\
\end{array}$ & \begin{tabular}{|l|}
$\mathrm{N}$ Over \\
16,000
\end{tabular} & Tota \\
\hline Stomach ulcers & - & 32.0 & 28.0 & 40.0 & 100 \\
\hline Surgical & - & 47.0 & 53.0 & - & 100 \\
\hline $\begin{array}{l}\text { treatment } \\
\text { Child birth }\end{array}$ & 47.0 & 37.047 .0 & 16.0 & 53.0 & 100 \\
\hline $\begin{array}{l}\text { Infectious and } \\
\text { parasitic } \\
\text { diseases }\end{array}$ & & & & & 100 \\
\hline $\begin{array}{l}\text { Acute } \\
\text { bronchitis }\end{array}$ & - & 15.0 & 47.0 & 38.0 & 100 \\
\hline Scabies & 48.0 & 29.4 & 23.0 & - & 100 \\
\hline Hypertension & - & 21.0 & 29.0 & 50.0 & 100 \\
\hline
\end{tabular}


60 Annals of the Social Council of Nigeria

Table 6

USE OF SINGLE FACILITY FOR DISEASE TYPES BY EDUCATION

$$
\mathrm{N}=170
$$

\begin{tabular}{|l|l|l|l|l|l|}
\hline $\begin{array}{l}\text { Selected health } \\
\text { cases }\end{array}$ & $\%$ & $\%$ & $\%$ & $\%$ & $\%$ \\
\cline { 2 - 6 } & $\begin{array}{l}\text { No edu- } \\
\text { cation }\end{array}$ & $\begin{array}{l}\text { Post- } \\
\text { sec- } \\
\text { ondary }\end{array}$ & $\begin{array}{l}\text { Post- } \\
\text { universit } \\
\text { y }\end{array}$ & $\begin{array}{l}\text { Tech- } \\
\text { nical }\end{array}$ & $\begin{array}{l}\text { Total } \\
\mathrm{i}\end{array}$ \\
\hline $\begin{array}{l}\text { Stomach ulcers } \\
\text { Surgical } \\
\text { treatments } \\
\text { Child birth } \\
\text { Infectious/parasiti } \\
\text { c diseases }\end{array}$ & - & 15 & 60 & 25 & 100 \\
Acute bronchitis & - & 5 & 70 & 20 & 100 \\
Scabies & - & 4 & 90 & 13 & 100 \\
Hypertension & - & - & - & - & 100 \\
\hline
\end{tabular}


Lagos Cosmopolitan and Multiple Health Services 61

Table 7

USE OF SINGLE FACILITY FOR DISEASE TYPES BY

OCCUPATION COSMOPOLITAN

\begin{tabular}{|c|c|c|c|c|c|}
\hline \multirow{2}{*}{\begin{tabular}{|l} 
Selected \\
cases
\end{tabular}} & $\%$ & $\%$ & $\%$ & $\%$ & $\%$ \\
\hline & $\begin{array}{l}\text { Unem- } \\
\text { ployed }\end{array}$ & $\begin{array}{l}\text { Profes- } \\
\text { sional }\end{array}$ & $\begin{array}{l}C M \\
\text { servant } \\
S\end{array}$ & $\begin{array}{l}\text { Self-em- } \\
\text { ployed } \\
\& \\
\text { Traders }\end{array}$ & Total \\
\hline Stomach ulcers & - & 60 & 25 & 15 & 100 \\
\hline $\begin{array}{l}\text { Surgical } \\
\text { treatments }\end{array}$ & - & 55 & 35 & 10 & 100 \\
\hline Child birth & - & - & 80 & 20 & 100 \\
\hline $\begin{array}{l}\text { Infectious/parasiti } \\
\text { c diseases }\end{array}$ & - & 65 & 25 & 10 & 100 \\
\hline Acute bronchitis & - & 25 & 60 & 15 & 100 \\
\hline Scabies & - & 15 & 75 & 10 & 100 \\
\hline Hypertension & - & 70 & 30 & - & 100 \\
\hline
\end{tabular}

\section{MULTIPLE USES OF FACILITIES BY DISEASE TYPES}

Tables 8,9 and 10 indicate the use of multiple health services by disease types. Cases reported are both in the psychosomatic and biophysical categories. The Tables show that traders and the self-employed generally use multiple health facilities for psychosomatic diseases in a greater proportion than those in other occupational cadres. Dreams, sleeplessness and excessive worries are all in the category of psychosomatic diseases which mostly require the therapeutic assistance of faith healing and tradomedical systems much more than cosmopolitan medical system. Similarly, a greater proportion of civil servants equally use non-cosmopolitan health facilities than those in the professional cadre for the treatment of psychosomatic diseases. The Table shows that the professional class in the study do not regard diseases such as coughs, stomach-aches, feverish conditions and general weakness of the body as health cases which require psychosomatic therapeutics.

Table 9 shows that exposure to university education seems to deter' the inordinate dependence on multiple health systems for the cure of psychosomatic problems. With the exception of "excessive worries", where $13 \%$ of the respondents with university education use multiple health systems as a therapeutic measure, no other disease in the psy 


\section{Table 8 \\ USE OF MULTIPLE SERVICES FOR SELECTED DISEASES/HEALTH PROBLEMS BY OCCUPATION OCCUPATION N $=680$}

\begin{tabular}{|l|l|l|l|l|}
\hline $\begin{array}{l}\text { Selected Health } \\
\text { Cases }\end{array}$ & $\begin{array}{l}\text { Profession } \\
\text { al }\end{array}$ & $\begin{array}{l}\text { Civil } \\
\text { servant }\end{array}$ & $\begin{array}{l}\text { Self- } \\
\text { employed } \\
\text { Traders }\end{array}$ & Total \\
\hline $\begin{array}{l}\text { Excessive } \\
\text { worries } \\
\text { Sleeplessness } \\
\text { Stomachache }\end{array}$ & 8.8 & 29.2 & 55.1 & 100 \\
Fevers \\
(Malaria/ \\
$\begin{array}{l}\text { Yellow fever) } \\
\text { Cough }\end{array}$ & 8.8 & 25.9 & 65.4 & 100 \\
General & 4.1 & 27.9 & 63.2 & 100 \\
weakness & 25 & 23.2 & 56.2 & 100 \\
Dreams & 6.6 & 13.6 & 80.0 & 100 \\
\hline
\end{tabular}

chosomatic category attracts as much respondents with university education. For example, while more than $51 \%$ of the respondents with post-secondary school and $41 \%$ of those in technical education use multiple health systems to cure sleeplessness only $7.3 \%$ of the respondents with university education do similarly. The greater reliance on multiple health systems by respondents without university education is not unconnected with the common perception that health systems such as faith healing, herbal medicine and other occultic measures have greater therapeutic efficacy in curing "excessive worries" than cosmopolitan medicine. In fact, such psychotherapeutic measures have been credited to non-biomedical systems by health analysts who see such measures as satisfying the psychological needs of the patient.

Table 10 indicates the use of multiple health services along the line of income. The Table reveals that respondents who earn over N8.00Q annually have more psychosomatic problems than those who earn less and that they also use multiple health systems with greater intensity. The Table also reveals that those earning less than 148,000 annually have simple biophysical diseases and equally use multiple 
Lagos Cosmopolitan and Multiple Health Services 63

Table 9

USE OF MULTIPLE SERVICES FOR SELECTED

DISEASES/HEALTH PROBLEMS BY EDUCATION

Education $\mathrm{N}=680$

\begin{tabular}{|c|c|c|c|c|}
\hline Selected Cases & \begin{tabular}{|l|} 
Post- \\
secondary
\end{tabular} & \begin{tabular}{|l|} 
Universit \\
$y$
\end{tabular} & $\begin{array}{l}\text { Technica } \\
l\end{array}$ & Total \\
\hline \begin{tabular}{|l} 
Excessive \\
worries
\end{tabular} & 55.1 & 13.0 & 31.7 & 100 \\
\hline Sleeplessness & 51.4 & 7.3 & 41.1 & 100 \\
\hline Stomachache & 57.3 & 7.3 & 35.2 & 100 \\
\hline $\begin{array}{l}\text { Fevers } \\
\text { (Malaria/ } \\
\text { Yellow fever) } \\
\text { Cough }\end{array}$ & 61.7 & 9.4 & 31.6 & 100 \\
\hline $\begin{array}{l}\text { General } \\
\text { weakness }\end{array}$ & 44.1 & 9.7 & 46.1 & 100 \\
\hline Dreams & 51.4 & 4.4 & 44.1 & 100 \\
\hline
\end{tabular}

health systems with greater intensity. The Table also reveals that those earning less than N8,000 annually have simple biophysical diseases and equally use multiple health systems with greater intensity to cure such ailments. It is noteworthy that respondents who earn more than $\mathrm{N} 16,000$ a year, and are probably traders/businessmen or in the professional class (such as s doctors, lawyers/engineers, etc.), use the therapeutic benefits of the multiple health systems with greater intensity much more than any other group.

\section{Discussion}

Proponents of acculturation hypothesis, have suggested a long time ago that acculturation will increase the utilisation of cosmopolitan medical facilities. The data presented in this study are not totally in consonance with such a hypothesis. Rather, the data indicate that the eclectic use of cosmopolitan medical facilities only function to reinforce the cultural integrity of a cultural group whose health cosmology is threatened by a non-indigenous health category. Therefore, catalysts of change, such as education and urban residence, had not 
Table 10

USE OF MULTIPLE SERVICES FOR SELECTED

DISEASE/HEALTH PROBLEMS BY INCOME

INCOME N $=680$

\begin{tabular}{|c|c|c|c|c|c|}
\hline $\begin{array}{l}\text { Selected Health } \\
\text { Cases }\end{array}$ & $\begin{array}{l}4,000- \\
8,000\end{array}$ & $\begin{array}{l}8,001 \\
12,000 \\
\end{array}$ & $\begin{array}{l}12.001 \\
16,000\end{array}$ & $\begin{array}{l}\text { Over } \\
16,000\end{array}$ & Total \\
\hline $\begin{array}{l}\text { Excessive } \\
\text { worries }\end{array}$ & 11.0 & 24.0 & 40.1 & 25.0 & 100 \\
\hline $\begin{array}{l}\text { Sleeplessness } \\
\text { Stomachache }\end{array}$ & 13.263 .5 & $\begin{array}{l}17.6 \\
25.2\end{array}$ & 29.69 .1 & $\begin{array}{l}39.8 \\
2.0\end{array}$ & $\begin{array}{l}100 \\
100\end{array}$ \\
\hline $\begin{array}{l}\text { Fever (Malaria/ } \\
\text { Yellow fever) }\end{array}$ & 62.0 & 19.1 & 11.0 & 8.2 & \\
\hline Cough & 55.0 & 28.5 & 710.4 & 6.1 & 100 \\
\hline $\begin{array}{l}\text { General } \\
\text { weakness }\end{array}$ & 44.0 & 33.4 & 14.5 & 7.5 & 100 \\
\hline Dreams & 6.6 & 23.5 & 29.4 & 40.4 & 100 \\
\hline
\end{tabular}

necessarily forced respondents to imbibe "modern" health behaviour; that is the rejection of non-cosmopolitan medical systems. This is because socio-cultural perceptions of health, disease and healing systems exert considerable influence on help-seeking behaviour of respondents, in so far as they believe that medicine consists of a vast complex knowledge, beliefs, values, customs, rituals and symbols which interlock to form mutually reinforcing and supporting systems. This is the medium which man has traditionally employed to deal with his major problems of health and disease.

It is evident from the study that the respondents maintain a specific pattern of multiple use for diseases perceived to be outside the biomedical categories. The study also reveals that residence in an urban environment does not necessarily eliminate reliance on faith healing or tradomedical services; neither does it enhance dependence on the services of cosmopolitan medicine. It demonstrates, nonetheless, that both the low class and the wealthy acculturated elites of Lagos metropolis use all the medical systems dualistically to gain both biophysical and psycho-social needs. For example, it is indicated in the study that the self-employed/traders suffer more breakdown resulting from excessive worries than the respondents in either the professional 
or civil service. This may not be unconnected with present uncertainties resulting from the Structural Adjustment Programme (SAP) which the Nigerian economy has been subjected to in recent times.

Traditionally, retail trading in Nigeria is heavily dependent on imported foreign goods which have become expensive because of cutbacks in importation; the resultant effects are uncertainties in the trading business. It is also indicated that more than $29 \%$ of respondents in the civil service cadre equally suffer from excessive worries which are really not unconnected with the current wave of retrenchments, and the air of uncertainty that has come to plague the civil service in recent times. The Nigerian civil service has lost its pre-eminent pre-independence position of glamour and job security because of politicisation. It is now the practice that whenever there is a new government, most especially military governments, the civil service is gripped with the fear of retrenchments and dismissals in the name of efficiency and accountability.

The data also reveal that respondents who are well-placed socio-economically have more psychosomatic problems and consequently utilise the services of the three systems simultaneously, much more than their less privileged counterparts. It demonstrates that a change in the material conditions of a cultural environment as a result of modernisation will not necessarily lead to the atomization of its socio-cultural institutions to the extent of rendering impotent the indigenous etiological and gnosological perception of health and disease. This is well demonstrated in Table 9, for example, as more than $65 \%$ of the respondents who earn well over N12,000 annually rely on both the cosmopolitan and tradomedical facilities as an antidote against excessive worries. The study also reveals that sleeplessness is a major health problem among those who earn high incomes. The simultaneous use of cosmopolitan and tradomedica! Facilities for malaria traverses all socio-economic groups. Although, it appears that the proportion of those who use all available medicines simultaneously for malaria seems to be more concentrated among respondents (62\%) who earn between N4,000 - N8,000 a year. Generally, the reliance on herbal conception as prophylactic medication against attack by malaria has gained greater clientele in recent times as a result of the rising costs of anti-malarial drugs.

Table 9, for example, shows that the degree of education of respondents does not necessarily reduce participation in the dual use of all health facilities. The findings show that respondents use all available health facilities as an antidote against excessive worries. It appears that the respondents with post-university education do not use all available medicines dualistically as much as those respondents with post-secondary and technical education. For example, while a mere $4.4 \%$ of the respondents use all medicines dualistically as an antidote 


\section{Annals of the Social Council of Nigeria}

against dreams, a high proportion of $44 \%$ and $51 \%$ of the respondents with a background of technical and post-secondary education do so respectively. It indicates that about $13 \%$ of respondents who are university educated, use both the indigenous and cosmopolitan health facilities to cure their excessive worries; while correspondingly, more than 55\% and $31 \%$ with post-secondary and technical education seek similar services.

\section{Conclusion}

Finally, it seems obvious from this study that pragmatism, rather than any other factor, determines the health behaviour of Lagos residents. Once the benefits of a health delivery system are visible, the study shows that no socio-economic groups discriminate against its use. As a result, people perceive cosmopolitan medicine to be a genuine therapeutic measure more for biophysical diseases than psychosomatic diseases. This is because nonscientific beliefs and healing seem to have become a residual category to fall back on whenever scientific explanations and cures fail. In the words of Berger and Luckman, belief in psychosomatic cure has "the power to produce reality". It shows that theories of disease can be produced by social as well as empirical support. Social validation is consequently outside the ambit of biomedical sciences. 
Lagos Cosmopolitan and Multiple Health Services

\section{References}

Ademuwagun, Z.A, 'The Relevance of Yoruba Medicine Man in Public Health Practice in Nigeria', Public Health Report 1969, Vol. 84, No. 12. pp.1085-91.

Behrhost, Carol: noughts on Community Services in Low Production, Physical Deprived Nations, Chimaltenango, Guatemala: Mimeo, 1973.

Berger, Peter L. and Thomas Luckman: The Social Construction of Reality, Garden City: Doubleday, Anchor Books, 1967.

Foster G.'.A Cross-Cultural Anthropological Analysis of a Technical Aid Programme, Washington, D.C: Smithsonial Institution, 1951.

"Relationships between Theoretical and Applied Anthopology", Human Organization 1972,31: 5-16.

Ganedo, Luis: "Rural Health Care in Mexico", Science, 1974, 185: 4157: 1131-37,1974.

Gusfied, Joseph R: "Tradition and Modernity: Misplaced Polarities in the Study of Social Change", American Journal of Sociology, 1967,72:351-62

Kane, Robert and Kane Roaslia: Federal Health Care (with Reservations), New York: Springar, 1972.

Lieben, Richard: Cubana Sorcery, Berkeley: University of California Press, 1967.

Lugard, Frederick The Dual Mandate in British Tropical Africa, Edingburgh and London: Blackwood and Sons, 1923.

Moloye, Olugbemi: "Patterns and Problems of Access to and Utilization of Health Care Services in Metropolitan Areas of Bauchi and Lagos", Ibadan: NISER, 1988.

Nolen, M.D. Williams: Healing, New York: Randon House, 1974.

Okosi, Anthonia T: "Manpower, Structure and Training Requirements for Local Governments: The Case of Lagos State", NISER Seminar Series, February 1988.

Schram, Ralph, A History of the Nigerian Health Services, Ibadan: Ibadan University Press, 1971

Simmions Ozzie G: "Popular and Modern Medicine in Mesitizo Communities of Coastal Peru and Chile", Journal of American Folklore, 1955, 68: 57-71. 